\title{
АГРАРНІ РОЗПИСКИ ЯК АЛЬТЕРНАТИВНИЙ ІНСТРУМЕНТ КРЕДИТУВАННЯ СІЛЬСЬКОГОСПОДАРСЬКИХ ТОВАРОВИРОБНИКІВ
}

\section{AGRICULTURAL RECEIPTS AS AN ALTERNATIVE TOOL FOR LENDING TO AGRICULTURAL PRODUCERS}

\author{
Печенюк Андрій Васильович \\ кандидат економічних наук, доцент, \\ Подільський державний аграрно-технічний університет \\ ORCID: https://orcid.org/0000-0002-8348-5044 \\ Pecheniuk Andrii \\ State Agrarian and Engineering University in Podilya
}

\begin{abstract}
Обґрунтовано актуальність проблеми належного фінансового забезпечення сільськогосподарських підприємств, зазначено про труднощі, які виникають при кредитуванні аграрного виробництва в Україні. Досліджено передумови впровадження аграрних розписок в Україні, законодавчу базу для використання такого інструменту фрінансування сільськогосподарського виробництва. Проаналізовано досвід і результати використання аграрних розписок фермерськими господарствами Бразилії. Розкрито умови та алгоритм реєстрації аграрних розписок, наведено розрахунок витрат, які супроводжують оформлення цього товаророзпорядчого документу. Проаналізовано сутність двох видів аграрних розписок: товарної та орінансової, зазначено про предмети зобов'язання, які застосовуються при кожній з них. У статті наголошується, що хоча при оформленні аграрних розписок передбачено можливість ефективного примусового їх виконання, слід пам'ятати, що така розписка - це передусім домовленість сторін, яка спрямована на реалізацію взаємовигідної мети, досягнути якої неможливо без поваги до прав іншої сторони та дотриманні взятих на себе зобов'язань. На основі аналізу світової та вітчизняної практики використання аграрних розписок узагальнено найбільш поширені моделі їх реалізації: 1) товарна чи фрінансова аграрна розписка у співпраці 3 постачальником матеріальнотехнічних ресурсів, послуг, техніки; 2) фрінансова аграрна розписка у співпраці з банком (плюс кредитний договір); 3) срінансова аграрна розписка у співпраці з кредитною спілкою (плюс кредитний договір); 4) товарна аграрна розписка у співпраці з трейдером чи переробником (плюс форвардний контракт). Проведено аналіз законопроектів, які знаходяться на розгляді парламенту стосовно фуункціонування та обігу аграрних розписок. Зроблено висновок, що аграрні розписки для вітчизняного сільськогосподарського бізнесу можуть стати саме тим інструментом, який допоможе подолати системну кризу у сфері виробництва та збуту аграрної продукції, відкриє нові можливості для розвитку галузі.

Ключові слова: аграрна розписка, фрінансове забезпечення, кредитування виробництва, сільськогосподарське виробництво, аграрна продукція, застава майбутнього урожаю, сільськогосподарська продукція, фрінансовий інструмент.
\end{abstract}

Обоснована актуальность проблемы надлежащего фринансового обеспечения сельскохозяйственных предприятий, указано о трудностях, которые возникают при кредитовании аграрного производства в Украине. Исследовано предпосылки внедрения аграрных расписок в Украине, законодательную базу для использования такого инструмента фринансирования сельскохозяйственного производства. Проанализирован опыт и результаты использования аграрных расписок фермерскими хозяйствами Бразилии. Раскрыты условия и алгоритм регистрации аграрных расписок, приведен расчет затрат, которые сопровождают оформление этого товарораспорядительного документа. Проанализированы сущность двух видов аграрных расписок: товарной и оринансовой, указано о предметах обязательства, которые применяются при каждой из них. В статье отмечается, что хотя при офрормлении аграрных расписок предусмотрена возможность эффективного принудительного исполнения, следует помнить, что такая расписка - это прежде всего договоренность сторон, направленная на реализацию взаимовыгодных целей, достичь которые невозможно без уважения к правам другой стороны и соблюдении взятых на себя обязательств. На основе анализа мировой и отечественной практики использования аграрных расписок обобщены наиболее распространенные модели их реализации: 1) товарная или фринансовая аграрная расписка в сотрудничестве с поставщиком материально-технических 
ресурсов, услуг, техники; 2) фринансовая аграрная расписка в сотрудничестве с банком (плюс кредитный договор); 3) фринансовая аграрная расписка в сотрудничестве с кредитным союзом (плюс кредитный договор); 4) товарная аграрная расписка в сотрудничестве с трейдером или переработчиком (плюс фрорвардный контракт). Проведен анализ законопроектов, находящихся на рассмотрении парламента относительно фрункционирования и обращения аграрных расписок. Сделан вывод, что аграрные расписки для отечественного сельскохозяйственного бизнеса могут стать именно тем инструментом, который поможет преодолеть системный кризис в ссрере производства и сбыта аграрной продукции, откроет новые возможности для развития отрасли.

Ключевые слова: аграрная расписка, финансовое обеспечение, кредитование производства, сельскохозяйственное производство, аграрная продукция, залог будущего урожая, сельскохозяйственная продукция, фринансовый инструмент.

The urgency of the problem of proper financial support of agricultural problems is substantiated, the difficulties that arise in lending to agricultural enterprise in Ukraine are noted. The preconditions for the introduction of agricultural receipts in Ukraine, the legal framework for the use of such a tool for financing agricultural production are studied. The experience and results of the use of agricultural receipts by farms in Brazil are analyzed. The conditions and algorithm of registration of agrarian receipts are revealed, the calculation of expenses accompanying registration of this commodity administrative document is resulted. The essence of two types of agricultural receipts is analyzed: commodity and financial, the subjects of the obligation which are applied at each of them are specified. The article emphasizes that although the registration of agricultural receipts provides for the possibility of effective enforcement, it should be remembered that such a receipt is primarily an agreement between the parties, which aims to achieve a mutually beneficial goal, which cannot be achieved without respect for the rights of the other party. commitments. Based on the analysis of world and domestic practice of using agricultural receipts, the most common models of their implementation are generalized: 1) commodity or financial agricultural receipt in cooperation with the supplier of material and technical resources, services, equipment; 2) financial agrarian receipt in cooperation with the bank (plus a loan agreement); 3) financial agrarian receipt in cooperation with the credit union (plus the loan agreement); 4) commodity agricultural receipt in cooperation with a trader or processor (plus a forward contract). An analysis of bills pending in parliament on the functioning and circulation of agricultural receipts has been made. It is concluded that agricultural receipts for domestic agricultural business can be just the tool that will help overcome the systemic crisis in the production and sale of agricultural products, will open new opportunities for industry development.

Keywords: agricultural receipt, financial provision, crediting of production, agricultural production, agricultural production, pledge of future harvest, agricultural production, financial instrument.

Постановка проблеми. Належний рівень фрінансування та доступне кредитування аграрного виробництва $€$ необхідними умовами забезпечення інноваційного розвитку сільського господарства, збалансованості продовольчого ринку, посилення експортного потенціалу країни.

Досить часто пошук джерел фрінансування для вітчизняних аграрних підприємств відбувається у несприятливих умовах. Залучення фрінансових ресурсів на світовому ринку шляхом боргових запозичень потребує відповідного досвіду розміщення єврооблігацій, якого ще бракує навіть менеджменту агрохолдингів. Останніми роками спостерігається процес уповільнення приросту інвестицій у реальний сектор країни. Як свідчить практика, аграрні підприємства в Україні відчувають значні труднощі при отриманні кредитів, адже банки, як правило, виставляють досить високі вимоги до застави, орієнтуються здебільшого на видачу «коротких» кредитів. Слід зазначити, що аграрний бізнес, ефрективність діяльності якого значною мірою залежить від сезонних явищ, часто змушений погоджуватися на невигідні для себе умови, маючи надію на отримання прибутку та своєчасний розрахунок з кредито- рами. Система кредитування через кредитні спілки не стала популярною.

Актуальність пошуку альтернативних інструментів фрінансового забезпечення аграрних підприємств зростає і вирішити проблему можна лише 3 максимальним врахуванням специфіки сільськогосподарського виробництва як суб'єкта кредитування. Одним із шляхів вирішення цієї проблеми може слугувати застосування на практиці механізму аграрних розписок, який набуває популярності в Україні останніми роками.

Популярність аграрних розписок із кожним роком зростає. Наразі оформити їх можна на всій території України. За інфрормацією, наведеною на сайті Державного підприємства «Аграрні реєстри», на початок 2021 року в Україні видано аграрних розписок на суму понад 32 млрд грн щодо 35 різноманітних сільськогосподарських культур [1].

Аграрні розписки за умови налагодження механізмів їх вільного обігу можуть стати як самостійним джерелом фрінансування, так і ліквідним забезпеченням за банківськими кредитами.

Аналіз останніх досліджень та публікацій. Проблемам фрінансового забезпечення сільськогосподарських товаровиробників при- 
свячено дослідження Анастасової К. [3], Зінчук Т. [11], Каменичної А. [5], Мацьківа В. [6], Томащука І. [9], Тулая О. [2], Урби С. [7]; пошук шляхів удосконалення фрінансово-кредитного забезпечення та виявлення резервів посилення фрінансового потенціалу аграрних підприємств відображено в публікаціях Готри В. [8], Мірошниченка В. [4], Фурсіної О. [10]; особливостям реалізації механізму аграрних розписок присвячені праці Зваруна Б. [17], Козюка 3. [13], Печенюка А., Рудика В. [21], Скоропада Б. [18]; недоліки та переваги використання аграрних розписок досить детально проаналізовано Заліською І. [16] та Лавріненком І. [19].

Виділення невирішених раніше частин загальної проблеми. Актуальним для аграрної ссрери України $є$ пошук інноваційних фрінансових інструментів, які були б корисними та економічно вигідними як для кредиторів, так і для сільськогосподарських підприємств. $€$ ще ряд невирішених проблем, які вимагають нових досліджень щодо визначення оптимальних шляхів фрінансового забезпечення аграрних підприємств. Зокрема, актуальним $€$ виявлення причин, через які попит на використання аграрних розписок зі сторони аграріїв не $є$ високим. Окрім цього, потребує систематизації сукупність бізнес-моделей, що можуть стати орієнтиром для початку роботи з цим фрінансовим інструментом.

Формулювання цілей статті (постановка завдання). Метою дослідження стало обґрунтування доцільності більш широкого використання аграрних розписок, як альтернативи банківському кредитуванню для сільськогосподарських виробників.

Теоретичною та методичною основою дослідження стали базові положення теорії фрінансів і наукові праці вітчизняних науковців, фрахівців з проблем фрінансового забезпечення аграрного виробництва. При цьому для розкриття сутності проблем ефективного ресурсного забезпечення аграрних виробників використано такі загальнонаукові методи як абстрагування, порівняння, аналіз і синтез. Метод узагальнення і системний підхід застосовано при виділенні основних бізнес-моделей, що використовуються для реалізації механізму аграрних розписок в Україні та світі. Для фрормулювання висновків дослідження використано абстрактно-логічний метод.

Виклад основного матеріалу дослідження. Аграрне виробництво $€$ одним 3 ключових секторів економіки України. Маючи за показниками родючості одні 3 найкращих у світі ґрунти, наша держава є провідним вироб- ником таких сільськогосподарських культур, як соняшник, пшениця, соя, кукурудза.

Окрім цього, сільське господарство $€$ джерелом сировинної бази для забезпечення розвитку переробних галузей країни, важливим партнером в інтеграційних фрормуваннях, а також основою для вирішення продовольчої безпеки держави.

Аграрна галузь значною мірою впливає на соціально-економічний розвиток держави, формуючи 14\% валової доданої вартості та понад 40\% експорту країни. Сільське господарство України майже на 90\% задовольняє потреби населення країни у продуктах харчування [2, с. 105].

Ефективний механізм фрінансового забезпечення діяльності аграрних підприємств $\epsilon$ однією 3 головних передумов їх конкурентоспроможності в умовах браку фрінансових ресурсів [3, с. 4].

Окрім того, від стану залучення та використання фрінансових ресурсів має пряму залежність фрінансовий потенціал аграрних підприємств. Потреба сільськогосподарських товаровиробників у доступних додаткових джерелах фрінансування має тенденцію до постійного зростання [4, с. 26].

Забезпечення фрінансовими ресурсами сільськогосподарського виробництва загалом залежить від економічної ситуації в державі. Нинішня практика фрінансового забезпечення сільськогосподарських товаровиробників не відзначається комплексністю та системністю, має низку недоліків, що не дають змоги задовольнити фрінансові потреби суб'єктів агропромислового виробництва [5, с. 106].

Інвестиційний процес в сільському господарстві характеризується порівняно невисокою рентабельністю та низьким рівнем окупності інвестицій, залежністю від одночасного впливу багатьох чинників: суб'єктивних і об'єктивних. Це досить часто викликає значні труднощі 3 пошуком інвесторів. Особливо загострюється ця проблема в умовах кризи [6, с. 278].

Кожна країна має свої особливості кредитування аграрної галузі, які визначаються станом розподільчих процесів, правовим режимом, фрінансово-економічним становищем [7, с. 40].

Слід зазначити, що складність проблеми ефрективного фрінансування аграрного виробництва викликана особливостями природи фуункціонування галузі: сезонність виробництва; тривалий період відтворення значної частини основних засобів; значний часовий інтервал між періодами здійснення витрат та отримання готової продукції; використання 
живих організмів в якості засобів та предметів праці; суттєва залежність результатів діяльності підприємства від впливу природно-кліматичних умов тощо [8, с. 120].

Обсяги інвестицій в сільське господарство України істотно відстають від аналогічних показників провідних держав світу - виробників аграрної продукції, насамперед, США, Канада, країни ЄС [9, с. 701].

Для ринкового середовища природною $\epsilon$ ситуація, при якій суб'єкт інвестування бажає залучити (придбати) позичкові кошти з мінімальними затратами, кредитор (продавець) бажає продати за максимально високою ціною [10, с. 277].

Серед особливих специфічних ознак аграрного виробництва слід виділити:

- сезонність виробництва;

- подовжений цикл виробництва (порівняно довга тривалість обігу капіталу в галузі);

- значна частина виробленої продукції залишається на підприємстві для власних потреб, що зменшує розмір можливого прибутку $[11$, с. 110$]$.

Поняття «аграрна розписка» вперше з'явилася в українському законодавстві у зв'язку прийняттям Закону України «Про аграрні розписки» від 06.11.2012 р., який набув чинності 19.03.2013 р. Саме цим законом для аграріїв було запроваджено новий механізм залучення коштів для ведення агробізнесу. Однак на практиці цей інструмент почав діяти аж у 2015 р. після затвердження низки відповідних підзаконних актів.

Згідно Закону України «Про аграрні розписки» аграрна розписка-товаророзпорядчий документ, що фріксує безумовне зобов'язання боржника, яке забезпечується заставою, здійснити поставку сільськогосподарської продукції або сплатити грошові кошти на визначених у ньому умовах [12].

Аграрні розписки запроваджено за проєктом Міжнародної фрінансової корпорації (IFC, одна 3 п'яти інституцій Групи Світового Банку) «Аграрні розписки в Україні» спільно 3 Мінагрополітики та Мін'юстом. Метою Проєкту задекларовано покращення доступу до фрінансових ресурсів для малих та середніх сільгоспвиробників шляхом запуску в Україні такого фрінансового інструменту, як аграрна розписка [13].

Ідея була запозичена в Бразилії, де, як і в Україні, фрермери не мали достатніх можливостей для ефрективного фрінансування через обмежену заставу. Проєкт та просрільні державні органи, партнери 3 громадського та приватного секторів забезпечили есрективне законодавче поле, запустили національний Реєстр аграрних розписок, розробили практичні вказівки та створили операційне середовище для роботи з аграрними розписками. Як результат, за 5 років було створено новий сегмент в агроорінансуванні, а аграрними розписками на постійній основі користуються агровиробники та кредитори з різних сегментів сільського господарства [14].

У Бразилії аграрні розписки використовують ще 3 90-х років минулого сторіччя. Щороку завдяки розпискам фрермери залучають понад 25 млрд дол. США для поповнення обігових коштів.

Розписка дає гарантії кредитору, до них не застосовують фрорс-мажор, можна пролонгувати заставу, вимоги кредитора пріоритетні, можна перевірити дані в єдиному реєстрі, який дає змогу створення кредитної історії як кредитору, так і боржникам.

За останні 20 років Бразилія увійшла до кола світових агропромислових лідерів та експортерів сільськогосподарських товарів. Лише виробництво зерна збільшилося з $60 \mathrm{млн} \mathrm{до} 200$ млн тонн. Загалом частка аграрного сектору становить 23\% ВВП та 44\% від загального експорту.

Досвід Бразилії велетенський, але й там $\epsilon$ що вдосконалювати. Існує багато ініціатив, щоб інтегрувати комерційне і банківське кредитування; вдосконалити процедури автоматизації та документообігу в рамках компаній, бо донині все провадиться на паперових носіях; сприяти юридичним змінам в законі про AP, щоб централізувати реєстрацію в електронній формі; затвердити доларову індексацію в законі про АР, аби заохотити іноземних інвесторів [15].

Аналогу механізму забезпечення, передбаченого Законом про аграрні розписки, в українському законодавстві немає. Аграрна розписка $\epsilon$ інструментом застави майбутнього урожаю. Оскільки на момент забезпечення зобов'язань предмету забезпечення ще не існує в натурі (врожай майбутній, через засуху чи інші погодні умови може не відповідати запланованим обсягам, якісним характеристикам тощо або взагалі не вродити), існують зрозумілі ризики для кредитора не отримати у майбутньому виконання фрінансових зобов'язань, а також не звернути стягнення на предмет застави через відсутність урожаю, або ж понести значні фрінансові збитки через невідповідність урожаю якісним характеристикам та обсягу [16]. 
Окрім того, урожай - це рухоме і швидкопсувне майно, яке можливо ідентифрікувати лише за видом, воно не містить індивідуальних особливостей. Фактично «заморозити» його як заставу нерухомості (заборона відчуження - нотаріус не проведе реєстрацію на нового власника, опломбування доступу до приміщення тощо), машини (містить реєстраційний номерний знак - заборона відчуження), устаткування (можна притримати до виконання зобов'язання тощо) неможливо.

Саме тому Законом про аграрні розписки введено низку положень, які включають специфріку предмета застави і при цьому захищають права кредитора та одночасно надають можливість виробнику (аграрію) фрінансуватись, навіть якщо у нього відсутній реальний предмет застави, нерухомість тощо [12].

Розписка вважається виданою 3 дня ії реєстрації у Реєстрі аграрних розписок, адміністратором якого є державне підприємство «Аграрні реєстри». Адміністратор гарантує доступ до інформації про видані аграрні розписки, які на момент звернення залишаються невиконаними. Реєстратор має право надавати інорормацію про видані аграрні розписки та історію їх обігу лише за згодою боржника або кредитора. У 299 нотаріусів $є$ доступ до Реєстру аграрних розписок. Тож цього року оформити аграрну розписку можна легко та без клопоту.

За посвідчення аграрної розписки нотаріусу сплачується державне мито в розмірі 0,01\% договірної вартості предмета застави, але не менше 5 і не більше 50 неоподатковуваних мінімумів доходів громадян (від 85 до 850 грн). За послуги приватного нотаріуса доведеться сплатити окремо за його розцінками, але не менше за ставку держмита. Крім того, сплачується:

- за внесення запису до Реєстру аграрних розписок - 355 грн;

- держреєстрацію обтяжень рухомого майна (додаток до постанови КМУ від 05.07.2004 р. № 830) - 60 грн;

- надання у паперовій фрормі витягу з Держреєстру обтяжень рухомого майна (додаток до Постанови № 830) - 70 грн.

Розрізняють два види аграрних розписок: товарна та фрінансова. Різниця між ними полягає у визначенні предмета зобов'язання окремо взятої аграрної розписки: у товарній аграрній розписці предметом зобов'язання $\epsilon$ поставка узгодженого сторонами виду сільськогосподарської продукції, а у фрінансовій розписці предметом зобов'язання $€$ сплата погодженої сторонами грошової суми [17].
Усі товарні аграрні розписки фріксують обсяг продукції, яку зобов'язаний поставити агровиробник (допускається лише перерахунок обсягу залежно від якості, але лише за умови, якщо в розписці вказана фрормула перерахунку). Натомість срінансові аграрні розписки можуть як фріксувати чітку суму грошових зобов'язань, так і містити фрормулу, за якою вони будуть розраховані в майбутньому на момент розрахунку (наприклад, з врахуванням коливань обмінного курсу валют чи майбутніх цін на продукцію). Фінансові аграрні розписки, за якими кредиторами є резиденти України, видаються лише в гривні, а «міжнародні» аграрні розписки, видані на нерезидентів, можуть бути в будь-якій валюті. Також, особливістю аграрних розписок $€$ вимога закону виражати розмір зобов'язань (і фріксований, і змінний) через формулу, яка враховує обсяги сільськогосподарської продукції.

Аграрна розписка видається окремо на кожний вид сільськогосподарської культури. Більшість 3 них забезпечена заставою майбутнього врожаю зернових і олійних культур, однак їх застосування можливе і в інших сегментах плодоовочівництва, органічної продукції, нішевих культур, продукції тваринництва. При офрормленні аграрної розписки нотаріус обов'язково зазначає в Державному реєстрі обтяжень рухомого майна як заставу врожай, а не земельну ділянку.

Офрормляючи аграрну розписку, боржник зобов'язується поставити майбутній урожай (товарна аграрна розписка), або сплатити грошові кошти на визначених у аграрній розписці умовах (фрінансова аграрна розписка), а таке зобов'язання забезпечується заставою майбутнього урожаю В аграрній розписці зазначаються кількісні та якісні показники сільськогосподарської продукції та перелік земельних ділянок, на яких вона повинна бути вирощеною [18].

Для належного нотаріального посвідчення аграрної розписки потенційному боржнику потрібно мати право власності на землю сільськогосподарського призначення або право користування такою земельною ділянкою на законних підставах для здійснення виробництва аграрної продукції, на якій знаходиться врожай, а також відсутність інших обтяжень на врожай на такій земельній ділянці.

При оформленні аграрної розписки нотаріус перевіряє фракт реєстрації права власності чи права користування земельними ділянками, що дає додаткові гарантії безпеки при оформленні та обігу аграрної розписки. Її виконання не повинно залежати від фракту оскарження чи 
недійсності положень забезпечуваного договору. Примусове виконання аграрної розписки здійснюється негайно шляхом офрормлення виконавчого напису нотаріуса [18].

Не зважаючи на можливість ефективного примусового виконання аграрних розписок слід пам'ятати, що така розписка - це передусім домовленість сторін, яка спрямована на реалізацію взаємовигідної мети, досягнути якої неможливо без поваги до прав іншої сторони та дотриманні взятих на себе зобов'язань.

Загалом, механізм кредитування за аграрною розпискою передбачає участь як мінімум двох суб'єктів, однак, досвід показує, що досить часто їх може бути й три. Так, сторонами правовідносин можуть бути:

1) аграрії (виробники сільськогосподарської продукції);

2) дистриб'ютори (посередники, які отримують аграрні розписки від аграріїв і виступають першими кредиторами);

3) постачальники, фрінансові установи, трейдери (отримують аграрні розписки від виробників або дистриб'юторів і виступають кінцевими кредиторами).

Як правило, дистриб'ютори надають аграріям товари, необхідні для вирощування продукції (насіння, добрива, засоби боротьби зі шкідниками тощо). Для дистриб'ютора цінність мають, зазвичай, кошти, які він бажає отримати за той товар, що був наданий аграрію. У цьому разі дистриб'ютор може відступити своє право третій особі. Такою особою стає трейдер, який восени або в інший час після збору урожаю звернеться до аграрія 3 вимогою поставити товар.

Така схема взаємовідносин надає аграрію суттєву перевагу перед кредитом, адже зобов'язання 3 поставки товару або сплати коштів у будь-якому разі прив'язано до збору урожаю. А у разі неврожаю дата виконання зобов'язань за погодженням 3 кредитором може бути перенесена на наступний маркетинговий рік [19].

Аграрні розписки використовуються агровиробниками та кредиторами 3 різних сегментів. Найпоширеніші ринкові практики було узагальнено в кілька основних бізнес-моделей, що можуть стати орієнтиром для початку роботи 3 інструментом. Можна виділити чотири основні моделі:

1. Товарна чи фрінансова аграрна розписка у співпраці 3 постачальником матеріальнотехнічних ресурсів, послуг, техніки. Кредитор-постачальник передає сільгоспвиробнику насіння, засоби захисту рослин, добрива, пальне, техніку тощо, а аграрне підприємство (фрермер) видає аграрну розписку для погашення заборгованості за отримані товари чи послуги. Фактично, розписка стає додатковим забезпеченням при товарному кредитуванні і використовується додатково до контракту на постачання товарів чи послуг.

2. Фінансова аграрна розписка у співпраці з банком (плюс кредитний договір). Аграрна розписка використовується як супровід до кредитного договору, їхні умови гармонізовані. Коли агровиробник виконує свої зобов'язання за кредитним договором, аграрна розписка вважається виконаною і може бути закрита.

3. Фінансова аграрна розписка у співпраці 3 кредитною спілкою (плюс кредитний договір). Трьохсторонній договір (між кредитною спілкою, фермерським господарством та членом спілки, від імені якого це господарство отримує кредит), з фрінансовою аграрною розпискою як додатком до цього договору.

4. Товарна аграрна розписка у співпраці 3 трейдером чи переробником (плюс форвардний контракт). Аграрна розписка може використовуватися як гарантія поставки чи збуту продукції паралельно з фрорвардним договором поставки (купівлі-продажу сільгосппродукції), як додаткове забезпечення. Після видачі розписки агровиробник може отримати передоплату від трейдера, а решта вартості аграрної продукції, як правило, оплачується після відвантаження [20].

Перед прийняттям рішення про надання орінансування кредитор, як правило, проводить процедуру фрінансово-економічного аналізу агровиробника. Такий аналіз може бути спрощеним (перевірка відкритих даних, руху грошових коштів по рахунках або онлайнповедінки в соціальних мережах, скоринг тощо) або повним: аналіз спроможності агровиробника повернути кредит (фрінансовий аналіз) та бажання це зробити (соціальноекономічний аналіз).

Наразі у парламенті на порядку денному сесії знаходиться законопроект № 2805-Д «Про внесення змін до деяких законодавчих актів України щодо фрункціонування та обігу аграрних розписок». Ним передбачається перетворення аграрних розписок у неемісійний цінний папір, що існує у формі електронного документу в реєстрі аграрних розписок. Це дозволить залучати рефінансування на вторинному ринку, отримавши доступ до ринків капіталу, як іноземних так, потенційно, і українського [1]. 
Важливо, що законодавчі зміни також забезпечать спрощення та здешевлення роботи 3 інструментом для користувачів. Наразі тільки нотаріальне посвідчення складає основну частину вартості роботи з інструментом, досягаючи 0,5\% від загальної вартості аграрної розписки або понад 30 тис гривень в середньому за видачу однієї розписки. Окрім цього агровиробники зможуть значно скоротити часові та транспортні витрати, адже за новою процедурою вони зможуть випускати аграрні розписки, не виходячи із дому або офрісу. За оцінками міністерства, лише за останні три роки сума економії на видачі аграрних розписок могла б скласти понад 1 млрд гривень.

Висновки. Аграрні розписки мають переваги як для сільськогосподарських товаровиробників, так і для кредиторів. Така фрорма кредитування дозволяє залучити додаткові фрінансові ресурси в сільське господарство, що свідчить про ефрективність аграрних розписок як інструмент успішного розвитку аграрного бізнесу в Україні [21].

Для агровиробників аграрні розписки - це можливість отримати кредитні ресурси під заставу майбутнього врожаю продукції на вигідних комерційних умовах. Окрім цього, завдяки публічному державному реєстру аграрії мають можливість фрормувати позитивну кредитну історію. Інструмент можуть використовувати фермерські господарства незалежно від розміру і спеціалізації, оскільки все, що потрібно, - це земля та майбутній урожай. Для кредиторів аграрні розписки - це надійний спосіб забезпечити виконання сільськогосподарськими товаровиробниками своїх зобов'язань. Цей механізм кредитування поєднує в собі конкурентні переваги інших інструментів, поширених в агросекторі та забезпечують найбільш оперативне отримання від агровиробника сільськогосподарської продукції або розрахунку грошима.

Аграрні розписки - це зазвичай зручніша та вигідніша альтернатива банківському кредитуванню для сільськогосподарських виробників. Цей кредитний інструмент активно застосовується у світі. Аграрні розписки можуть стати для українського агробізнесу саме тим інструментом, який допоможе подолати системну кризу у сорері виробництва та збуту сільськогосподарської продукції, відкриє нові можливості для розвитку галузі.

\section{СПИСОК ВИКОРИСТАНИХ ДЖЕРЕЛ:}

1. Аграріям потрібен оновлений закон про аграрні розписки. URL: https://landlord.ua/news/ahrariiampotriben-onovlenyi-zakon-pro-ahrarni-rozpyskyl (дата звернення: 12.02.2021).

2. Тулай О. Сучасний стан та проблеми фінансового забезпечення сталого розвитку агропромислового сектору. Світ фонансів. 2018. № 3(56). С. 104-116.

3. Анастасова К.А. Механізм фрінансового забезпечення розвитку аграрних підприємств. Молодий вчений. 2017. № 1.1 (41.1). C. 1-5.

4. Мірошніченко В.О. Резерви посилення фінансового потенціалу аграрних підприємств. Науковий вісник Ужгородського національного університету. 2017. № 12. С. 24-28.

5. Каменична А.М. Неврегульовані питання фрінансового забезпечення аграрного сектору економіки держави. Економіка АПК. 2019. № 1. С. 104-111.

6. Мацьків В.В. Складові фрінансового забезпечення розвитку аграрного сектору. Сталий розвиток економіки. 2015. № 3(28). С. 277-281.

7. Урба С.І., Червона О.Ю. Аналіз фінансового забезпечення розвитку аграрного сектору економіки України. Бізнес-навігатор. 2019. № 2(51). С. 37-41.

8. Готра В. Умови та напрямки вдосконалення фінансово-кредитного забезпечення інноваційного розвитку аграрного сектору економіки України. Актуальні проблеми економіки. 2015. № 5(167). С. 117-123.

9. Томашук І.В. Проблеми та перспективи фрінансового забезпечення аграрного сектору Вінницького регіону. Глобальні та національні проблеми економіки. 2017. № 20. С. 698-704.

10. Фурсіна О.В. Основні джерела фрінансування та ризики в інвестуванні аграрних підприємств. Науковий вісник НЛтУ України. 2014. Вип. 24.3. С. 274-281.

11. Зінчук Т.А. Проблеми фрінансового забезпечення сільськогосподарських підприємств. Науковий вісник Херсонського державного університету. 2014. № 9. Частина 1. С. 109-112.

12. Закон України «Про аграрні розписки» № 5479-VI від 06.11.2012 (із змінами). URL: https://zakon.rada.gov.ua/ laws/show/5479-17\#Text (дата звернення: 21.02.2021).

13. Козюк 3. Аграрні розписки - зручний інструмент кредитування аграріїв. URL: https://uteka.ua/ua/ publication/agro-4-shkola-bughaltera-selkokhozyastvenoy-otrasli-69-agrarnye-raspiski---udobnyj-instrumentkreditovaniya-agrariev (дата звернення: 24.03.2021). 
14. Аграрні розписки - ефективний інструмент фрінансування агровиробників України. URL: https://balance.ua/news/ post/agrarnie-raspiski-effektivniy-instrument-finansirovaniya-agroproizvoditeley-ukraini (дата звернення: 04.03.2021).

15. Аграрні розписки: Україна - Бразилія. URL: https://agroexpert.ua/ahrarni-rozpysky-ukraina-brazyliia/ (дата звернення: 18.03.2021).

16. Заліська І. Аграрні розписки: переваги та недоліки використання. URL: https://esquires.ua/agrarnirozpysky-perevagy-ta-nedoliky-vykorystannya/ (дата звернення: 27.02.2021).

17.Зварун Б. Аграрні розписки: поняття та особливості використання. Юридична газета. 2019. № 28-29. С. 682-683. URL: http://yur-gazeta.com/publications/practice/zemelne-agrarne-pravo/agrarni-rozpiskiponyattya-ta-osoblivosti-vikoristannya.html (дата звернення: 30.01.2021).

18. Скоропад Б. Як працюють аграрні розписки. Юридична газета. 2019. № 32. URL: http://yur-gazeta.com/ publications/practice/inshe/yak-pracyuyut-agrarni-rozpiski.html (дата звернення: 24.03.2021).

19. Лавріненко І. (2019) Аграрна розписка як фрорма альтернативного кредитування. Юридична газета. 2019. № 7. URL: http://yur-gazeta.com/dumka-eksperta/agrarna-rozpiska-yak-forma-alternativnogo-kredituvannya.html (дата звернення: 02.03.2021).

20. Аграрні розписки: довідник на основі матеріалів та напрацювань Проєкту IFC «Аграрні розписки в Україні», що реалізується у 2015-2020 роках за підтримки Державного секретаріату Швейцарії з економічних питань (SECO). URL: https://ukravit.ua/wp-content/uploads/2019/12/Agrarni-rozpiski-gid-dlya-pochatkivtsiv-2019.pdf (дата звернення: 26.02.2021).

21. Pecheniuk A., Rudyk V. Agrarian receipts as a form of lending to agricultural producers. Problèmes et perspectives d'introduction de la recherche scientifique innovante: collection de papiers scientifiques «^○ГО $\Sigma$ » avec des matériaux de la conférence scientifique et pratique internationale (Vol. 1), 29 Novembre, 2019. Bruxelles, Belgique : Plateforme scientifique européenne. P. 7-9.

\section{REFERENCES:}

1. Ahrariiam potriben onovlenyi zakon pro ahrarni rozpysky [Farmers need an updated law on agricultural receipts]. Available at: https://landlord.ua/news/ahrariiam-potriben-onovlenyi-zakon-pro-ahrarni-rozpysky/ (accessed 12 February 2021).

2. Tulai O. (2018). Suchasnyi stan ta problemy finansovoho zabezpechennia staloho rozvytku ahropromyslovoho sektoru [Current state and problems of financial support of sustainable development of the agro-industrial sector]. Svit finansiv [The world of finance], no. 3(56), pp. 104-116.

3. Anastasova K.A. (2017). Mekhanizm finansovoho zabezpechennia rozvytku ahrarnykh pidpryiemstv [The mechanism of financial support for the development of agricultural enterprises]. Molodyi vchenyi [A young scientist], no. 1.1 (41.1), pp. 1-5.

4. Miroshnichenko V.O. (2017). Rezervy posylennia finansovoho potentsialu ahrarnykh pidpryiemstv [Reserves for strengthening the financial potential of agricultural enterprises]. Naukovyi visnyk Uzhhorodskoho natsionalnoho universytetu [Scientific Bulletin of Uzhhorod National University], no. 12, pp. 24-28.

5. Kamenychna A.M. (2019). Nevrehulovani pytannia finansovoho zabezpechennia ahrarnoho sektoru ekonomiky derzhavy [Unresolved issues of financial support of the agricultural sector of the state economy]. Ekonomika APK [Economics of agro-industrial complex], no. 1, pp. 104-111.

6. Matskiv V.V. (2015). Skladovi finansovoho zabezpechennia rozvytku ahrarnoho sektoru [Components of financial support for the development of the agricultural sector]. Stalyi rozvytok ekonomiky [Sustainable economic development], no. 3(28), pp. 277-281.

7. Urba S.I., Chervona O.Iu. (2019). Analiz finansovoho zabezpechennia rozvytku ahrarnoho sektoru ekonomiky Ukrainy [Analysis of financial support for the development of the agricultural sector of the Ukrainian economy]. Biznes-navihator [Business navigator], no. 2(51), pp. 37-41.

8. Hotra V. (2015). Umovy ta napriamky vdoskonalennia finansovo-kredytnoho zabezpechennia innovatsiinoho rozvytku ahrarnoho sektoru ekonomiky Ukrainy [Conditions and directions of improvement of financial and credit maintenance of innovative development of agrarian sector of economy of Ukraine]. Aktualni problemy ekonomiky [Current economic problems], no. 5(167), pp. 117-123.

9. Tomashuk I.V. (2017). Problemy ta perspektyvy finansovoho zabezpechennia ahrarnoho sektoru Vinnytskoho rehionu [Problems and prospects of financial support of the agricultural sector of Vinnytsia region]. Hlobalni ta natsionalni problemy ekonomiky [Global and national economic problems], no. 20, pp. 698-704.

10. Fursina O.V. (2014). Osnovni dzherela finansuvannia ta ryzyky v investuvanni ahrarnykh pidpryiemstv [The main sources of financing and risks in investing in agricultural enterprises]. Naukovyi visnyk NLTU Ukrainy [Scientific Bulletin of NLTU of Ukraine], no. 24.3, pp. 274-281. 
11. Zinchuk T.A. (2014). Problemy finansovoho zabezpechennia silskohospodarskykh pidpryiemstv [Problems of financial support of agricultural enterprises]. Naukovyi visnyk Khersonskoho derzhavnoho universytetu [Scientific Bulletin of Kherson State University], no. 2014/9, pp. 109-112.

12. Zakon Ukrainy «Pro ahrarni rozpysky» № 5479-VI vid 06.11.2012 (iz zminamy) [Law of Ukraine "OnAgrarian Receipts" № 5479-VI of November 6, 2012 (as amended)]. Available at: https://zakon.rada.gov.ua/laws/show/5479-17\#Text (accessed 21 February 2021).

13. Koziuk Z. Ahrarni rozpysky - zruchnyi instrument kredytuvannia ahrariiv [Agricultural receipts are a convenient tool for lending to farmers]. Available at: https://uteka.ua/ua/publication/agro-4-shkola-bughaltera-selkokhozyastvenoy-otrasli-69-agrarnye-raspiski---udobnyj-instrument-kreditovaniya-agrariev (accessed 24 March 2021).

14. Ahrarni rozpysky - efektyvnyi instrument finansuvannia ahrovyrobnykiv Ukrainy [Agricultural receipts are an effective tool for financing Ukrainian agricultural producers]. Available at: https://balance.ua/news/post/ agrarnie-raspiski-effektivniy-instrument-finansirovaniya-agroproizvoditeley-ukraini (accessed 04 March 2021).

15. Ahrarni rozpysky: Ukraina - Brazyliia [Agricultural receipts: Ukraine - Brazil]. Available at: https://agroexpert.ua/ ahrarni-rozpysky-ukraina-brazyliia/ (accessed 18 March 2021).

16. Zaliska I. Ahrarni rozpysky: perevahy ta nedoliky vykorystannia [Agricultural receipts: advantages and disadvantages of use]. Available at: https://esquires.ua/agrarni-rozpysky-perevagy-ta-nedoliky-vykorystannya/ (accessed 27 February 2021).

17.Zvarun B. (2019). Ahrarni rozpysky: poniattia ta osoblyvosti vykorystannia [Agricultural receipts: concepts and features of use]. Yurydychna hazeta [Legal newspaper], no. 28-29, pp. 682-683. Available at: http://yur-gazeta.com/ publications/practice/zemelne-agrarne-pravo/agrarni-rozpiski-ponyattya-ta-osoblivosti-vikoristannya.html (accessed 30 January 2021).

18. Skoropad B. (2019). Yak pratsiuiut ahrarni rozpysky [How agricultural receipts work]. Yurydychna hazeta [Legal newspaper], no. 32. Available at: http://yur-gazeta.com/publications/practice/inshe/yak-pracyuyut-agrarnirozpiski.html (accessed 24 March 2021).

19. Lavrinenko I. (2019). Ahrarna rozpyska yak forma alternatyvnoho kredytuvannia [Agricultural receipt as a form of alternative lending]. Yurydychna hazeta [Legal newspaper], no. 7. Available at: http://yur-gazeta.com/dumka-eksperta/agrarna-rozpiska-yak-forma-alternativnogo-kredituvannya.html (accessed 02 March 2021).

20. Ahrarni rozpysky: dovidnyk na osnovi materialiv ta napratsiuvan Proiektu IFC «Ahrarni rozpysky v Ukraini», shcho realizuietsia u 2015-2020 rokakh za pidtrymky Derzhavnoho sekretariatu Shveitsarii z ekonomichnykh pytan (SECO) [Agricultural receipts: a guide based on the materials and developments of the IFC Agricultural Receipts in Ukraine Project, implemented in 2015-2020 with the support of the Swiss State Secretariat for Economic Affairs (SECO)]. Available at: https://ukravit.ua/wp-content/uploads/2019/12/Agrarni-rozpiski-gid-dlya-pochatkivtsiv-2019.pdf (accessed 26 February 2021).

21. Pecheniuk A., Rudyk V. (2019). Agrarian receipts as a form of lending to agricultural producers. Problèmes

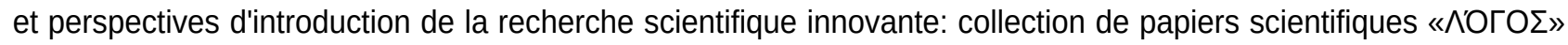
avec des matériaux de la conférence scientifique et pratique internationale, vol. 1, 29 Novembre, 2019. Bruxelles, Belgique: Plateforme scientifique européenne, pp. 7-9. 